\title{
Omówienie książki Janusza Rybakowskiego pt. „Lit - niezwykły lek w psychiatrii”, Wydawnictwo Termedia, Poznań 2019
}

Książka prof. Janusza Rybakowskiego pt. „Lit - niezwykły lek w psychiatrii” zawiera opis zastosowania tytułowego pierwiastka w terapii zaburzeń psychicznych. Co ważne, ta publikacja nie jest zwykłym kompendium litoterapii.

W pierwszym rozdziale omówiono w barwny sposób historię badań nad litem, przedstawiając sylwetki badaczy i klinicystów, którzy przyczynili się do wprowadzenia go do armamentarium psychiatrycznego. Szczegółowo i z ogromną sympatią opisany został Mogens Schou, niestrudzony badacz i orędownik litu. Kolejne rozdziały poświęcone są chorobom afektywnym $\mathrm{i}$ ich leczeniu. Zgodnie z tytułem książki głównym bohaterem jest węglan

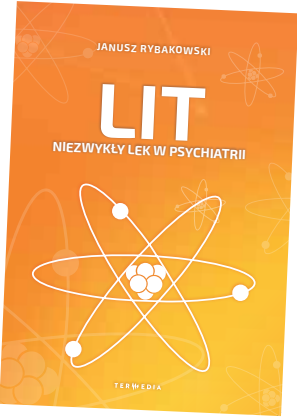
litu. W rozdziale 8 autor opisuje sposób rozpoczynania kuracji litem (co jest szczególnie ważne dla lekarzy w trakcie specjalizacji z psychiatrii). W kolejnym zawarte są opisy przeciwmaniakalnego działania litu oraz potencjalizacji działania leków przeciwdepresyjnych. Część książki poświęcona normotymicznemu działaniu litu w chorobie afektywnej dwubiegunowej (ChAD) zawiera wyniki badań wykazujących jego skuteczność w tym zakresie (nie zabrakło tu danych z ośrodka poznańskiego). Dużo uwagi autor poświęca czynnikom związanym z odpowiedzią na lit, opisuje grupę pacjentów, w której stosowanie litu wiąże się z ustąpieniem nawrotów choroby (tzw. excellent lithium responders). Bardzo ważne dla lekarzy praktyków są rozdziały: 12 (objawy niepożądane stosowania litu i postępowanie w przypadku ich wystąpienia), 13 (interakcje litu z innymi lekami) oraz 15 (stosowanie litu w ciąży i okresie poporodowym). W kolejnych rozdziałach autor omawia działanie przeciwwirusowe, zapobiegające samobójstwom, neuroprotekcyjne oraz wpływ litu na funkcje poznawcze pacjentów z ChAD - temat szczególnie dla mnie ważny.

Lit jako lek w psychiatrii ma długą, znacząca, ale i burzliwą historię. Były okresy, w których wydawało się, że zostanie odsunięty na plan dalszy, zastąpiony przez inne leki normotymiczne. Przełomowym momentem w historii litu była publikacja wyników badania BALANCE w czasopiśmie „Lancet” w 2010 r. Od tego czasu wzrosło zainteresowanie tym pierwiastkiem, mówi się nawet o renesansie litu. Wydaje się jednak, że renesans dotyczy głównie świata nauki, powstają nowe interesujące prace, jednak w praktyce klinicznej lit jest zbyt rzadko stosowany.

Książka „Lit - niezwykły lek w psychiatrii” jest wynikiem wieloletniej pasji autora, zainteresowania litem jako pierwiastkiem i jako lekiem, jest próbą rekapitulacji badań wyjaśniających mechanizm działania litu, jak również badań klinicznych nad jego skutecznością. Kluczowe wydaje się, że autor książki uczestniczył w wielu wydarzeniach naukowych poświęconych chorobom afektywnym, publikował prace na ten temat, uczestniczył w badaniach wieloośrodkowych, dyskusjach na konferencjach czy forach eksperckich.

Dlaczego ta książka jest ważna i potrzebna? Lit stanowi złoty standard leczenia ChAD i niezwykle cenne jest opracowanie, które przekłada wiedzę na codzienną praktykę kliniczną. Wartość tej publikacji wynika z połączenia encyklopedycznej wiedzy autora na temat litu oraz jego doświadczenia klinicznego. Książka stanowi wyczerpujący przegląd wiedzy nie tylko na temat litu per se, ale także obrazu klinicznego i leczenia chorób afektywnych, może zatem stanowić praktyczny przewodnik w codziennej praktyce klinicznej. Dane amerykańskie wskazują, że rezydenci psychiatrii, którzy mają niewystarczającą wiedzę na temat litu, mniej chętnie go przepisują. Należy pamiętać, że ok. $30 \%$ pacjentów leczonych litem to tzw. excellent lithium responders, czyli osoby bez nawrotów, których życie (jak to określa kanadyjski psychiatra Paul Grof) zostało zmienione przez lit. Być może dzięki tej książce więcej pacjentów z chorobami afektywnymi otrzyma właściwą diagnozę i leczenie.

Książka „Lit - niezwykły lek w psychiatrii” została wydana jesienią 2019 r., kilka miesięcy później rozpoczęła się pandemia COVID-19. Prowadzenie pacjentów z zaburzeniami psychicznymi, zwłaszcza leczonych litem, którego stosowanie wymaga monitorowania, jest teraz szczególnie trudne. Tym bardziej książka na temat litu jest przydatna. Ale lit i pandemia to nie tylko trudność w terapii. Być może lit stanie się znów obiektem zainteresowania w aspekcie działania przeciwwirusowego (to działanie zostało omówione w rozdziale 17 książki). Niedawno, 20 maja 2020 r., w czasopiśmie „International Journal of Bipolar Disorders” ukazała się praca pt. „Lithium’s 
antiviral effects: a potential drug for COViD-19 disease?”. Autorami publikacji są badacze z Międzynarodowej Grupy Badań nad Litem (International Group for the Study of Lithium Treated Patients - IGSLi), a wśród nich prof. Janusz Rybakowski. Przeprowadzony w artykule przegląd wskazuje, że w badaniach przedklinicznych lit ma wyraźne działanie przeciwwirusowe, potrzebne są jednak badania w warunkach klinicznych. Nie wydaje się prawdopodobne szerokie stosowanie litu przeciw COVID-19 w populacji ogólnej, ale powstaje wiele pytań związanych z jego działaniem na rodzinę koronawirusów, a zwłaszcza SARS-CoV-2. Czy terapia litem u pacjentów z ChAD będzie miała wpływ na częstość występowania u nich COVID-19 i przebieg tej choroby? Czy terapia litem będzie miała wpływ na decyzje terapeutyczne w przypadku zachorowania pacjenta z ChAD? Czy lit okaże się jeszcze bardziej niezwykłym pierwiastkiem? Odpowiedzi znajdziemy zapewne w kolejnym wydaniu książki „Lit - niezwykły lek w psychiatrii”.

dr hab. Aleksandra Suwalska, prof. UM Zaktad Zdrowia Psychicznego Katedry Psychiatrii, Uniwersytet Medyczny im. Karola Marcinkowskiego w Poznaniu e-mail: asuwalska@ump.edu.pl 